\title{
PERTUMBUHAN SEMAI SENGON (Paraserianthes falcataria (L.) Nielsen) PADA MEDIA TANAH BEKAS TAMBANG KAPUR DENGAN PENAMBAHAN PUPUK KOMPOS DAN NPK
}

\author{
Growth of Paraserianthes falcataria (L.) Nielsen Seedling on Limestone Mining Site's Soil \\ Added with Compost and NPK Fertilizer
}

Basuki Wasis $^{1^{*}}$ dan Siti Halimatus Sa'idah ${ }^{1}$

(Diterima Januari 2019/Disetujui Maret 2019)

\begin{abstract}
Limestone mining activities are damaging soil and enviroment. Revegetation becomes an obligation on every mining sites. Paraserianthes falcataria is one of many species that suitable to be planted in revegetation site. Adding compost and NPK fertilizer can improve soil's condition. This research objective is to analyze the effect of compost and NPK fertilizer on Paraserianthes falcataria seedlings growth and the exact appropriate dosage for limestone mining's soil condition improvement. The design used in this research is completely randomized design with two factors. The result shows that addtion of compost on tailing media doesn't give major effect or statistically not significant on seedling growth of height, diameter, the amount of root nodules, and shoot-root ratio, but statistically significant on wet and dry weight of the seedlings. NPK fertilizer addition on tailing media is statistically significant on the seedling growth of diameter, wet weight, and shoot-root ratio, but not significant different on height, dry weight, and the amount of root nodules. Interaction between compost and NPK fertilizer on media gives effect only at $95 \%$ of confidence level. K1N5 sample (with 100 gram composts and 5 gram of NPK fertilizer) gives the best respond on seedling's growth. Very high levels of $\mathrm{Ca}$ in the soil medium will be toxic to the Paraserianthes Falcataria plant.
\end{abstract}

Keys word : Compost, limestone mining, NPK fertilizer, Paraserianthes falcataria

\section{PENDAHULUAN}

Indonesia merupakan negara yang sangat kaya akan hasil hutan, meliputi keanekaragaman jenis makhluk hidup dan kekayaan bahan atau material tambang. Salah satu material tambang yang tersedia adalah batu kapur. Batu kapur merupakan bahan baku utama dalam pembuatan semen. Sebagai bahan dalam bentuk kalsium karbonat $\left(\mathrm{CaCO}_{3}\right)$, batu kapur juga dibutuhkan untuk berbagai penggunaan setelah diubah menjadi kapur mentah $(\mathrm{CaO})$ atau kapur mati $(\mathrm{CaOH})$ seperti misalnya dalam industri-industri farmasi, makanan, dan kertas. Sebanyak $80 \%$ dari bahan baku pembuatan semen terdiri atas batu kapur, dan tidak kurang dari 50 juta ton batu kapur dibutuhkan setiap tahun untuk memenuhi proses pembuatan semen di semua pabrik semen di Indonesia (Prayudyaningsih dan Sari 2016).

Dampak negatif penambangan bahan galian C (batu kapur) antara lain adalah hilangnya solum tanah, lapisan tanah menjadi bercampur dengan batuan, terjadi peningkatan bulk density (pemadatan) dan kelembaban tanah, serta penurunan permeabilitas dan kesuburan tanah (Cahyani dan Hardjana 2017; Wasis et al 2018). Masalah tersebut dilanjutkan dengan kebiasaan beberapa penambang yang meninggalkan lahan bekas tambang tersebut. Setelah cadangannya habis pihak perusahaan tidak melakukan kegiatan pemulihan

\footnotetext{
${ }^{1}$ Dept. Silvikultur Fakultas Kehutanan IPB

* Penulis Korespondensi:

E-mail: basuki_wasis@yahoo.com
}

terhadap lingkungan yang rusak. Jika kegiatan rehabilitasi terhadap lingkungan dan ekosistem lahan pasca tambang tersebut dikhawatirkan akan menyebabkan penurunan mutu lingkungan.

Revegetasi menjadi kegiatan yang wajib dilakukan pada lahan bekas penambangan, namun seringkali upaya revegetasi menghadapi kendala yang cukup berat. Pada lahan bekas tambang membutuhkan jenis tanaman yang mampu beradaptasi pada daerah kering dan miskin unsur hara. Sengon (Paraserianthes falcataria (L.) Nielsen) merupakan salah satu tanaman yang tidak membutuhkan persyaratan tumbuh tinggi karena mampu hidup pada tanah miskin hara. Sengon juga merupakan jenis tanaman komersil yang menguntungkan dan termasuk jenis cepat tumbuh (fast growing species) sehingga cocok untuk revegetasi lahan bekas tambang (Zulkifli 2013, Baskorowati 2014).

Upaya-upaya yang dapat dilakukan untuk meningkatkan pertumbuhan tanaman pada lahan bekas tambang kapur adalah dengan memperbaiki kualitas tanah dan menyediakan nutrisi untuk tanaman. Diantaranya adalah melalui aplikasi pemupukan. Pupuk yang digunakan merupakan pupuk alami (kompos) dan pupuk anorganik/buatan seperti pupuk NPK. Kompos merupakan pupuk organik yang mengandung unsur hara makro dan mikro serta mampu memperbaiki struktur tanah. Penelitian ini bertujuan untuk menganalisis pengaruh penambahan pupuk NPK dan kompos terhadap pertumbuhan bibit sengon (Paraserianthes falcataria (L.) Nielsen) pada media bekas tambang kapur. 


\section{METODE PENELITIAN}

\section{Waktu dan Tempat Penelitian}

Waktu dan Tempat. Penelitian dilaksanakan mulai bulan Maret - September 2018 di rumah kaca bagian Silvikultur Departemen Silvikultur Fakultas Kehutanan IPB, Laboratorium Pengaruh Hutan Departemen Silvikultur Fakultas Kehutanan IPB, dan analisis tanah di Laboratorium Departemen Ilmu Tanah dan Sumberdaya Lahan Fakultas Pertanian IPB. Sementara itu, lokasi pengambilan sampel tanah bekas penambangan kapur dilakukan di Ciampea, Kecamatan Ciampea, Kabupaten Bogor, Jawa Barat.

\section{Alat dan Bahan}

Alat-alat yang digunakan dalam penelitian ini adalah timbangan digital, sekop kecil, polybag dengan ukuran $20 \mathrm{~cm} \times 20 \mathrm{~cm}$, alat penyiram, penggaris, kaliper, tallysheet, alat dokumentasi, Microsoft excel 2007 dan SAS versi 9.1 portable. Sedangkan, bahan yang digunakan dalam penelitian ini adalah semai Sengon (Falcataria moluccana Miq.) yang berumur 3 bulan, pupuk NPK (Ponska 15- 15-15), kompos, dan media tanam berupa tanah bekas penambangan kapur.

\section{Prosedur Penelitian}

Penelitian ini terdiri dari beberapa tahapan, yaitu persiapan, pemindahan bibit atau penyapihan, pemeliharaan, pengamatan dan pengambilan data, serta rancangan percobaan dan analisis data.

\section{Persiapan}

Tahap persiapan meliputi penyiapan media tanam. Media tanam yang digunakan merupakan tanah bekas tambang kapur yang berasal dari Ciampea Bogor. Limbah tambang kapur tersebut ditimbang seberat $1 \mathrm{~kg}$ dalam keadaan kering udara dan dicampurkan dengan kompos dan pupuk NPK yang komposisinya sesuai dengan perlakuan yang diujicobakan. Semai yang digunakan adalah semai sengon yang berumur 3 bulan.

\section{Penyapihan}

Bibiti sengon yang berumur 3 bulan dipindahkan ke dalam media yang telah dipersiapkan. Pemindahan semai ini dilakukan pada waktu sore hari dengan tujuan untuk mengurangi terjadinya penguapan pada semai sengon.

\section{Pemeliharaan}

Pemeliharaan semai sengon meliputi penyiraman sebanyak dua kali sehari, yaitu pagi dan sore hari. Penyiraman dilakukan dengan mempertimbangkan kondisi media tanam di dalam polybag.

\section{Pengamatan dan Pengambilan Data}

Parameter yang diukur adalah tinggi, diameter, berat basah, berat kering, jumlah bintil akar dan analisis unsur hara. Pengukuran tinggi semait sengon dilakukan dengan menggunakan mistar dari pangkal batang yang telah ditandai dengan cat (1 cm diatas media) sampai titik tumbuh pucuk apikal. Pengukuran diameter semai sengon dilakukan dengan menggunakan caliper digital.
Pengukuran tinggi dan diameter dilakukan selama 3 bulan. Berat basah total diukur pada akhir pengamatan. Bibit sengon dipanen kemudian dipisahkan bagian akar dan pucuk lalu ditimbang dengan menggunakan timbangan. Berat basah total merupakan penjumlahan antara berat basah akar dengan berat basah pucuk. Berat kering diukur setelah bagian tanaman dikeringkan dalam oven pada suhu $80^{\circ} \mathrm{C}$ selama 24 jam, kemudian bagian akar dan pucuk tanaman yang telah dioven ditimbang. Berat kering total diperoleh dengan menjumlahkan berat kering akar dengan berat kering pucuk. Jumlah bintil akar diukur dengan memisahkan bintil akar dengan akarnya kemudian dihitung jumlahnya. Nisbah pucuk akar (NPA) dihitung berdasarkan perbandingan nilai berat kering total pucuk dengan nilai kering total akar. Analisis unsur hara dilakukan pada akhir pengamatan. Sample yang diambil sebanyak tiga sampel yaitu kontrol, perlakuan yang memiliki pertumbuhan terbaik dan perlakuan dengan dosis maksimum.

\section{Rancangan Percobaan dan Analisis Data}

Rancangan percobaan yang digunakan adalah rancangan faktorial dengan desain Acak Lengkap dengan dua faktor (Sastrosupadi 2000; Stell dan Torries. 1991). Faktor pertama yaitu pupuk NPK yang terdiri dari 4 taraf (N0: $0 \mathrm{~g}$, N5 : $5 \mathrm{~g}, \mathrm{~N} 10: 10 \mathrm{~g}$ dan N15 : $15 \mathrm{~g}$ ), faktor kedua yaitu kompos yang terdiri dari 4 taraf (K0 : 0 g, K1: 100g, K2: $200 \mathrm{~g}$ dan K3: 300g).

Data yang diperoleh berdasarkan pengamatan dan pengukuran, kemudian dianalisis dengan menggunakan model linier. Data diolah menggunakan software SAS 9.1, Nilai $\mathrm{P}$-value $<\alpha(0,05)$, maka perlakuan memberikan pengaruh nyata terhadap tinggi, diameter, berat basah total, berat kering total, jumlah bintil akar, dan NPA, kemudian dilanjutkan dengan uji lanjut Duncan's Multiple Range Test.

\section{HASIL DAN PEMBAHASAN}

Berdasarkan hasil penelitian menunjukkan bahwa pemberian pupuk kompos secara tunggal pada media tailing tidak memberikan pengaruh secara nyata terhadap tinggi tanaman, diameter, jumlah bintil akar dan nisbah pucuk akar. Namun memberikan berpengaruh secara nyata terhadap berat basah dan berat kering tanaman. Begitu juga dengan pemberian pupuk NPK secara tunggal memberikan pengaruh secara nyata terhadap diameter tanaman, berat basah dan nisbah pucuk akar, namun tidak berpengaruh secara nyata terhadap tinggi tanaman, berat kering dan jumlah bintil akar. Sementara interaksi pemberian pupuk kompos dan pupuk NPK hanya berpengaruh nyata terhadap parameter diameter tanaman (Tabel 1).

Berdasarkan hasil uji duncan/uji lanjut dari hasil sidik ragam terhadap pertumbuhan diameter menunjukkan bahwa interaksi perlakuan dosis K1N5 (Pupuk Kompos 100 gram NPK 5 gram) menghasilkan pertumbuhan diameter terbaik dibandingkan dengan perlakuan dosis lainya (Tabel 2). Interaksi terhadap pemupukan NPK dan kompos mampu meningkatkan 
pertumbuhan sebesar $170.37 \%$ terhadap kontrol dengan rata-rata pertumbuhan diameter $0.24333 \mathrm{~cm}$ selama dalam kurun waktu 13 minggu penelitian.

Pemberian pupuk NPK dengan dosis 4-8 gram/polybag mampu meningkatkan tinggi, jumlah daun, panjang akar dan diameter pada tanaman Codiaeum variegatum L. Pupuk NPK merupakan pupuk yang menyediakan unsur hara esensial yang sangat dibutuhkan untuk pertumbuhan semai/bibit. Nitrogen (N) merupakan unsur utama pada kebanyakan senyawa organic tanaman antara lain asam amino, enzim, klorofil, ADP. ATP sehingga kekurangan $\mathrm{N}$ dapat menghabat pertumbuhan dan reproduksi tanaman (Adinugraha 2012).)). Namun demikian pemberian pupuk $\mathrm{N}$ tidak boleh berlebihan karena $\mathrm{N}$ dalam konsentrasi tinggi akan menghambat perakaran bibit (Rosman et al. 2004, El-Aziz 2007) Kompos merupakan bahan organik yang telah mengalami dekomposisi oleh mikroorganisme pengurai sehingga dapat dimanfaatkan untuk memperbaiki sifat-sifat tanah, disamping itu di dalam kompos terkandung hara-hara mineral yang berfungsi untuk penyediaan makanan bagi tanaman. Selain itu, kompos juga berguna untuk bioremidiasi (Wasis dan Sandrasari 2011).

Berdasarkan Gambar 1 menunjukkan bahwa

Tabel 1 Rekapitulasi hasil sidik ragam penambahan pupuk kompos dan NPK terhadap parameter pertumbuhan semai sengon

\begin{tabular}{lccc}
\hline & \multicolumn{3}{c}{ Perlakuan } \\
\cline { 2 - 4 } \multicolumn{1}{c}{ Parameter } & $\begin{array}{l}\text { Pupuk } \\
\text { Kompos }\end{array}$ & NPK & $\begin{array}{l}\text { Pupuk } \\
\text { Kompos } \\
+ \text { NPK }\end{array}$ \\
\hline Tinggi & $0.2078 \mathrm{tn}$ & $0.1209 \mathrm{tn}$ & $0.1403 \mathrm{tn}$ \\
Diameter & $0.0924 \mathrm{tn}$ & $0.0029^{*}$ & $0.0429^{*}$ \\
$\begin{array}{l}\text { Berat Basah } \\
\text { Berat Kering }\end{array}$ & $0.0053^{*}$ & $0.0263^{*}$ & $0.2981 \mathrm{tn}$ \\
$\begin{array}{l}\text { Jumlah Bintil } \\
\text { Akar } \\
\text { Nisbah Pucuk }\end{array}$ & $0.5582 \mathrm{tn}$ & $0.1295 \mathrm{tn}$ & $0.8073 \mathrm{tn}$ \\
Akar & $0.8213 \mathrm{tn}$ & $0.0238^{*}$ & $0.2503 \mathrm{tn}$ \\
\hline * perlakuan & berpengaruh & nyata pada & selang \\
$\quad$ kepercayaan 95\% & & \\
tn $=$ perlakuan tidak berpengaruh nyata &
\end{tabular}

perlakuan K1N5 (Pupuk Kompos 100 gram NPK 5 gram) memiliki rata-rata total laju pertumbuhan diameter tertinggi dibandingkan dengan perlakuan yang lainya. Rata-rata total laju pertumbuhanya sebesar 2.43 $\mathrm{mm}$ dalam kurun waktu 13 minggu penelitian. Perlakuan K1N5 merupakan perlakuan terbaik dengan persentase peningkatan $170.37 \%$ terhadap control, hal tersebut menunjukkan bahwa perlakuan telah memberikan unsur hara dan perbaikan sifat tanah lebih baik.

Berdasarkan hasil uji duncan/uji lanjut dari hasil sidik ragam pengaruh penambahan pupuk kompos terhadap berat basah total tanaman menunjukkan bahwa perlakuan dengan dosis kompos 100 gram memiliki rata-rata tertinggi dibandingkan dengan ketiga perlakuan dosis lainya (Tabel 3). Pada pemberian pupuk kompos dengan dosis 100 gram mampu memberikan persentase peningkatan sebesar $23.16 \%$ terhadap kontrol dengan rata-rata berat basah total 21.188 gram. Dengan

Tabel 2 Hasil uji Duncan pengaruh penambahan pupuk kompos dan NPK terhadap pertumbuhan diameter bibit sengon

\begin{tabular}{ccc}
\hline Perlakuan & $\begin{array}{c}\text { Rata-rata } \\
\text { pertumbuhan } \\
\text { diameter }(\mathrm{cm})\end{array}$ & $\begin{array}{c}\text { Persen } \\
\text { Peningkatan }\end{array}$ \\
\hline K1N5 & $0.24333 \mathrm{a}$ & 170.37 \\
K1N10 & $0.24000 \mathrm{a}$ & 166.67 \\
K2N0 & $0.22667 \mathrm{ab}$ & 151.86 \\
K0N5 & $0.20667 \mathrm{abc}$ & 129.63 \\
K1N0 & $0.19000 \mathrm{abc}$ & 111.11 \\
K2N5 & 0.17667 abcd & 96.30 \\
K2N10 & 0.17333 abcd & 92.59 \\
K3N0 & 0.16333 abcde & 81.48 \\
K3N10 & 0.16000 abcde & 77.78 \\
K3N5 & 0.15667 abcde & 74.08 \\
K0N10 & 0.13667 bcde & 51.86 \\
K0N15 & 0.13333 bcde & 48.14 \\
K2N15 & 0.13333 bcde & 48.14 \\
K3N15 & 0.12000 cde & 33.33 \\
K0N0 & 0.09000 de & 0.00 \\
K1N15 & 0.07667 e & -14.81 \\
\hline Keterangan: & Angka yang diikuti oleh huruf yang & menunjukkan \\
& sama & merlakuan tidak \\
& berbeda nyata pada selang kepercayaan
\end{tabular}

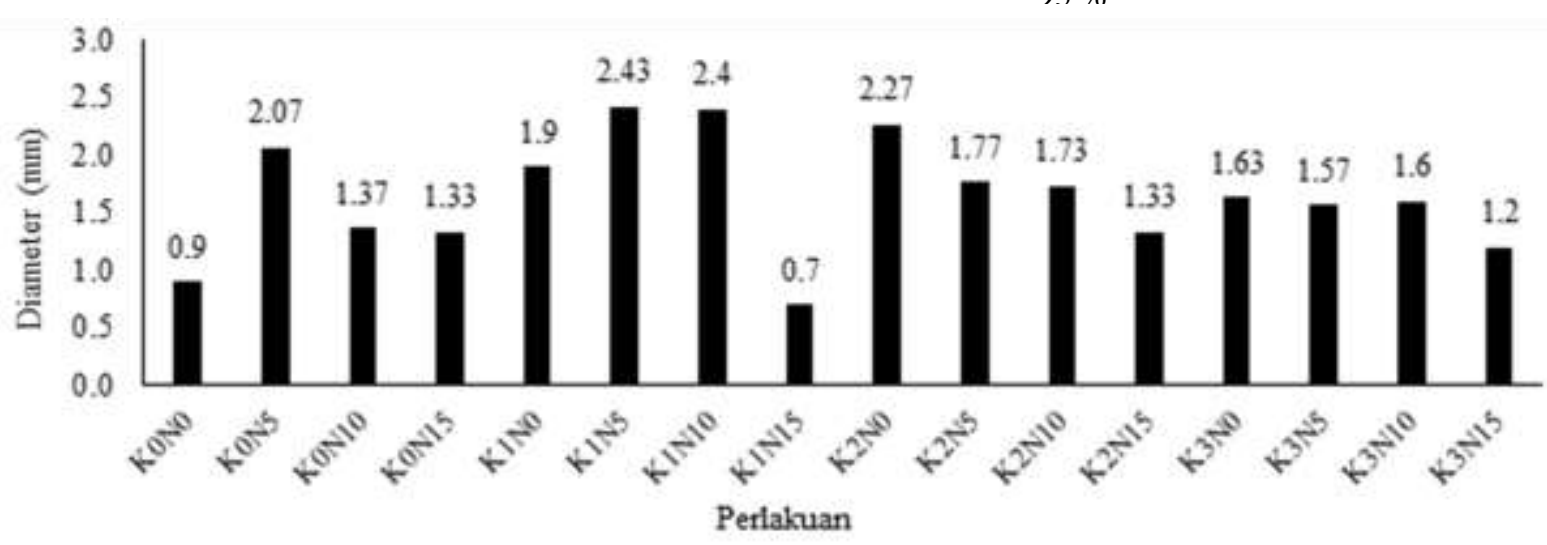

- Total L aju Pertum buhan

Gambar 1 Rata-rata total laju pertumbuhan diameter semai sengon pada berbagai dosis perlakuan 
memberikan pupuk kompos pada media tailing akan meningkatkan unsur hara dalam media tanah. Pemberian Kompos pada tanah akan meningkatkan unsur tanah, memperbaiki struktur tanah dan membaiki media tumbuh akar tanaman. Apabila proses pengambilan air dan unsur hara berjalan normal maka proses fotosintesis juga akan berjalan dengan baik dan menghasilkan asimilat/hasil fotosintesis yang lebih banyak sehingga menyebabkan berat basah semai tanaman meningkat (Wasis dan Fathia 2011).

Berdasarkan hasil uji duncan penambahan pupuk NPK terhadap berat basah total tanaman menunjukkan bahwa perlakuan dengan dosis NPK 5 gram memiliki rata-rata tertinggi dibandingkan dengan ketiga perlakuan dosis lainya (Tabel 4). Pada pemberian pupuk NPK dengan dosis 5 gram mampu memberikan persentase peningkatan sebesar $5.92 \%$ terhadap kontrol dengan rata-rata berat basah total 19.488 gram. Pemberian unsur $\mathrm{N}$ yang berlebih akan bersifat racun bagi tanaman. Unsur $\mathrm{N}$ cukup tersedia bagi tanaman maka kandungan klorofil pada daun akan meningkat dan proses fotosintesis juga meningkat sehingga asimilat yang dihasilkan lebih banyak, akibatnya pertumbuhan tanaman lebih baik. Apabila asimilat yang dihasilkan lebih banyak maka berat dari semai juga akan mengalami peningkatan. Selain itu unsur K juga berperan penting dalam proses fotosintesis. Unsur hara

Tabel 3 Hasil uji Duncan pengaruh penambahan pupuk kompos terhadap berat basah bibit sengon

\begin{tabular}{lcc}
\hline Perlakuan & $\begin{array}{c}\text { Rata-rata Berat } \\
\text { Basah (gram) }\end{array}$ & $\begin{array}{c}\text { Persen } \\
\text { Peningkatan }\end{array}$ \\
\hline $\begin{array}{l}\text { Kompos } \\
\text { 0 gram }\end{array}$ & $17.203 \mathrm{ab}$ & 0 \\
$\begin{array}{l}\text { Kompos } \\
100 \text { gram }\end{array}$ & $21.188 \mathrm{a}$ & 23.16 \\
$\begin{array}{l}\text { Kompos } \\
\text { 200 gram }\end{array}$ & $16.555 \mathrm{~b}$ & -3.77 \\
$\begin{array}{l}\text { Kompos } \\
\text { 300 gram }\end{array}$ & $13.417 \mathrm{~b}$ & -22.01 \\
\hline
\end{tabular}

Keterangan: Angka yang diikuti oleh huruf yang sama menunjukkan perlakuan tidak berbeda nyata pada selang kepercayaan $95 \%$.

Tabel 4 Hasil uji Duncan pengaruh penambahan pupuk NPK terhadap berat basah bibit sengon

\begin{tabular}{lcc}
\hline \multicolumn{1}{c}{ Perlakuan } & $\begin{array}{c}\text { Rata-rata berat } \\
\text { basah (gram) }\end{array}$ & $\begin{array}{c}\text { Persen } \\
\text { Peningkatan }\end{array}$ \\
\hline $\begin{array}{l}\text { Pupuk NPK } \\
0 \text { gram }\end{array}$ & $18.399 \mathrm{a}$ & 0 \\
$\begin{array}{l}\text { Pupuk NPK } \\
5 \text { gram }\end{array}$ & $19.488 \mathrm{a}$ & 5.92 \\
$\begin{array}{l}\text { Pupuk NPK } \\
10 \text { gram }\end{array}$ & $17.063 \mathrm{ab}$ & -7.26 \\
$\begin{array}{l}\text { Pupuk NPK } \\
15 \text { gram }\end{array}$ & $13.413 \mathrm{~b}$ & -27.10 \\
\hline Keterangan: & $\begin{array}{l}\text { Angka yang diikuti oleh huruf yang } \\
\text { sama menunjukkan perlakuan tidak } \\
\text { berbeda nyata pada selang kepercayaan } \\
\end{array}$ & $\begin{array}{l}\text { 95 \%. } \\
\text { manda }\end{array}$
\end{tabular}

$\mathrm{K}$ berfungsi dalam proses fotosintesis dengan memperlancar proses masuknya $\mathrm{CO}_{2}$ melalui stomata, transport fotosintat, air dan gula serta sintesis protein dan gula (Tania et al. 2012), Unsur hara K diserap tanaman dalam bentuk ion $\mathrm{K}^{+}$dan jumlahnya dalam tanah cukup bervariasi. Kalium dalam tanah berada dalam bentuk $\mathrm{K}$ dalam larutan, $\mathrm{K}$ dapat dipertukarkan dan $\mathrm{K}$ tidak dapat dipertukarkan.

Pada tanah lahan kering seperti pada media tailing tambang kapur hara $\mathrm{K}$ dalam kondisi yang rendah,sehingga pemupukan sangat diperlukan. Demikian pula senyawa posfor sangat esensial dalam proses fotosintesis, metabolisme asam amino dan oksidasi biologis. Ketiga unsur hara makro seperti N, P dan $\mathrm{K}$ sangat berkaitan erat dengan proses berjalanya fotosintesis dan pembentukan asimilat. Sehingga apabila ketiga unsur tersebut ketersediaanya optimal didalam tanah maka proses fotosintesis juga dapat berjalan dengan normal dan optimal sehingga mendukung bertambahnya jumlah asimilat dan berat basah pada semai tanaman sengon (Hardjowigeno 2003).

Berdasarkan hasil uji duncan penambahan pupuk kompos terhadap berat kering total tanaman menunjukkan bahwa perlakuan dengan dosis pupuk kompos 100 gram memiliki rata-rata tertinggi dibandingkan dengan ketiga perlakuan dosis lainya (Tabel 5). Pada pemberian pupuk kompos dengan dosis 100 gram mampu memberikan persentase peningkatan sebesar $26.60 \%$ terhadap kontrol dengan rata-rata berat kering total 4.9575 gram. Parameter pertumbuhan tanaman yang berhubungan dengan pengaruh lingkungan yaitu bobot kering total atau biomassa.

Biomassa adalah parameter penting yang dapat mewakili tanaman dikatakan tumbuh secara optimal sebab biomassa menggambarkan hasil fotosintesis yang dipengaruhi laju asimilasi bersih dan luas daun pertanaman yang dinyatakan dengan nilai bobot kering tanaman setelah dilakukan pengeringan sehingga pertumbuhan tanaman berbanding lurus dengan nilai biomasssa tanaman tersebut (Sukendreo dan Sugiarto 2012).

Berdasarkan uji lanjut/Duncan pemberian pupuk kompos 100 gram mampu memberikan persentase peningkatan $23.16 \%$ terhadap kontrol pada berat basah

Tabel 5 Hasil uji Duncan pengaruh penambahan pupuk kompos terhadap berat kering bibit sengon

\begin{tabular}{lcc}
\hline \multicolumn{1}{c}{ Perlakuan } & $\begin{array}{c}\text { Rata-rata } \\
\text { Berat Kering } \\
\text { (gram) }\end{array}$ & $\begin{array}{c}\text { Persen } \\
\text { Peningkatan }\end{array}$ \\
\hline $\begin{array}{l}\text { Kompos } \\
0 \text { gram }\end{array}$ & $3.9158 \mathrm{ab}$ & 0 \\
$\begin{array}{l}\text { Kompos } \\
100 \text { gram }\end{array}$ & $4.9575 \mathrm{a}$ & 26.60 \\
$\begin{array}{l}\text { Kompos } \\
200 \text { gram }\end{array}$ & $3.9300 \mathrm{ab}$ & 0.36 \\
$\begin{array}{l}\text { Kompos } \\
300 \text { gram }\end{array}$ & $2.8492 \mathrm{~b}$ & -27.24 \\
\hline Keterangan: & $\begin{array}{l}\text { Angka yang diikuti } \\
\text { sama menunjukkan huruf yang } \\
\text { berbeda nyata } \\
\text { merlakuan tidak } \\
\text { pada selang } \\
\text { kepercayaan 95\%. }\end{array}$
\end{tabular}


total dan $26.60 \%$ terhadap kontrol pada berat kering total tanaman. Serta pemberian pupuk NPK 5 gram mampu memberikan persentase peningkatan $5.92 \%$ terhadap kontrol pada berat kering total tanaman.

Hasil persentase peningkatan yang negatif terhadap kontrol menunjukkan bahwa tanaman di duga mengalami penurunan pertumbuhan yang dikarenakan dosis pemberian pupuk berlebihan akan bersifat neracun (Tabel 3, 4 dan 5). Secara keseluruhan pada perlakuan dengan dosis 15 gram NPK memberikan hasil berat basah dan berat kering yang lebih rendah apabila dibandingkan pada dosis perlakuan pupuk NPK 5 dan 10 gram. Menurut Koesriningrum dan Setiyati dalam (Rosman et al. (2004). Pemberian pupuk N tidak boleh berlebihan karena $\mathrm{N}$ dalam konsentrasi tinggi akan menghambat perakaran bibit. Apabila perakaran bibit terhambat maka penyerapan air dan unsur hara juga terganggu, sehingga proses fotosintesis menjadi tidak berjalan normal serta fotosintat yang dihasilkan menjadi rendah. Apabila hasil fotosintat yang dihasilkan rendah maka berat basah total dan berat kering total yang dihasilkan juga akan rendah. Selain itu dosis pemberian kompos yang berlebihan juga dapat membuat pertumbuhan tanaman tidak optimal, karena pupuk kompos juga mengandung unsur hara seperti N,P, K dan unsur yang lainya. Sehingga menyebabkan akumulasi unsur $\mathrm{N}$ yang terserap pada semai menjadi berlebihan.

Pemberian pupuk NPK secara tunggal memberikan pengaruh secara nyata terhadap nisbah pucuk akar semai sengon. Informasi mengenai nisbah pucuk akar diperlukan untuk mengetahui keseimbangan antara pertumbuhan pucuk tanaman sebagai tempat terjadinya proses fotosintesis dengan pertumbuhan akar sebagai bidang serapan unsur hara dan air (Wulandari et al. 2011). Berdasarkan hasil uji lanjut/Duncan menunjukkan bahwa dosis pemberian pupuk NPK sebesar 5 gram memiliki NPA yang paling tinggi yaitu sebesar sebesar 5.4675 (Tabel 6). Peningkatan NPA menunjukkan bahwa kualitas tanman semakin tidak baik.

Hasil penelitian menunjukkan bahwa nilai nisbah pucuk akar pada berbagai perlakuan semai sengon adalah sebesar 2.03-8.35. Nilai ini cukup besar jika dibandingan dengan literatur yang menunjukkan bahwa nilai NPA yg baik antara 1-3. Perlakuan K1N15 memiliki nilai NPA yang paling kecil diantara perlakuan lainnya. Hal ini menandakan bahwa

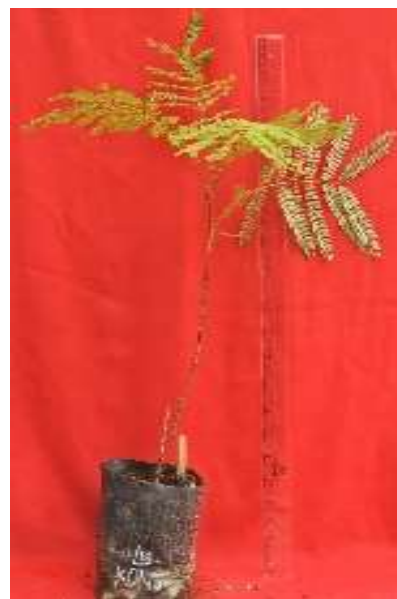

K0

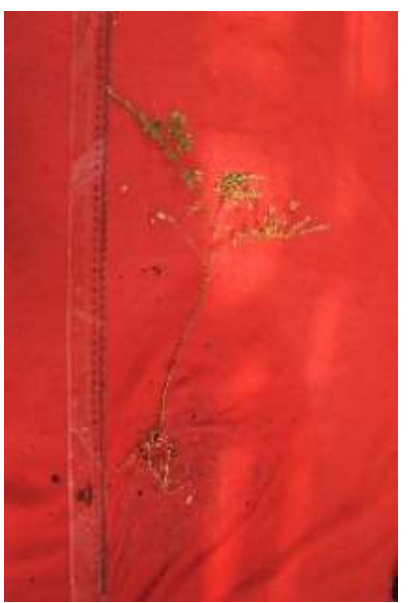

K0

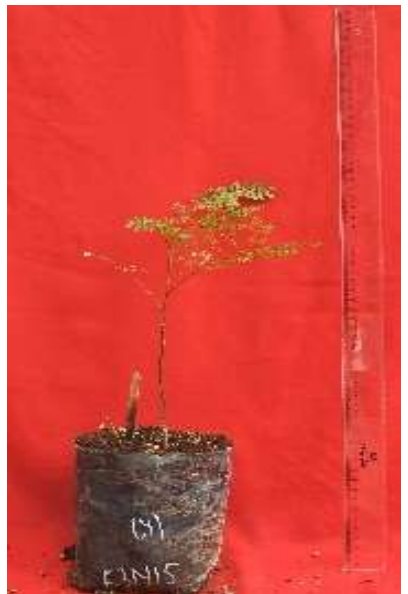

K3N

(a)

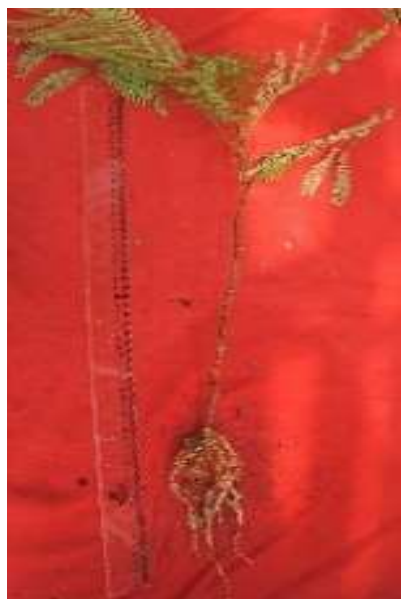

K3N

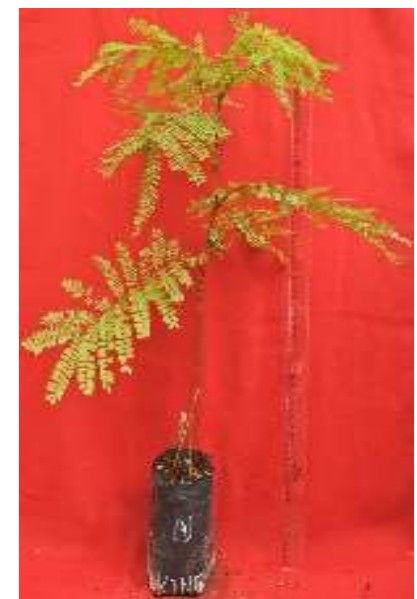

K1

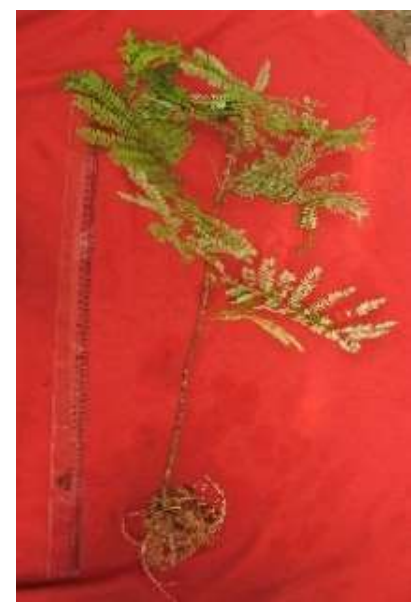

K1

(b)

Sumber: Dokumentasi pribadi

Gambar 2 Penampakan semai sengon (a) Sebelum dipanen, (b) Setelah dipanen 
penambahan pupuk NPK dan kompos dapat mengoptimalkan perkembangan akar untuk meningkatkan serapan air dan hara (Salisbury dan Ross 1992; Rahmawati et al. 2013).

Hasil analisa tanah menunjukkan bahwa tanah bekas tambang kapur dengan pemberian pupuk kompos dan NPK mampu memperbaiki kondisi fisik, biologi dan kimia tanah. Pemberian pupuk NPK dan kompos dapat meningkatkan kandungan unsur hara pada media tanaman untuk C organik sebesar $5 \%, \mathrm{~N}$ sebesar $0.24 \%$ , P sebesar 200.14 ppm, K sebesar $14.71 \mathrm{me} / 100 \mathrm{~g}$ dan $\mathrm{Mg}$ sebesar 6,5 me/100g.

Selain itu, pemupukan kompos dan NPK juga dapat menurunkan jumlah kalsium yang ada dalam media tanah sebesar 0,85 me/100 g. Menurut Ginting et al. (2013). Hara Kalium (K), Calsium (Ca), dan Magnesium $(\mathrm{Mg})$ merupakan hara makro yang banyak dikaji keseimbangannya. Hal ini disebabkan ketiga hara tersebut saling berinteraksi satu dengan lainnya di dalam tanah, dengan kata lain konsentrasi salah satu hara yang terlalu tinggi dapat menyebabkan hara yang lainnya menjadi tertekan. Penelitian ini juga menunjukkan bahwa Ca yang sangat tinggi akan bersifat toksik bagi tanaman sengon.

Tabel 6 Hasil uji Duncan pengaruh penambahan pupuk NPK terhadap nisbah pucuk akar bibit sengon

\begin{tabular}{lcc}
\hline \multicolumn{1}{c}{ Perlakuan } & $\begin{array}{c}\text { Rata-rata nisbah } \\
\text { pucuk akar }\end{array}$ & $\begin{array}{c}\text { Persen } \\
\text { Peningkatan }\end{array}$ \\
\hline $\begin{array}{l}\text { Pupuk NPK } \\
\text { 0 gram }\end{array}$ & $3.0225 \mathrm{~b}$ & 0 \\
$\begin{array}{l}\text { Pupuk NPK } \\
5 \text { gram }\end{array}$ & $5.4675 \mathrm{a}$ & 80.89 \\
$\begin{array}{l}\text { Pupuk NPK } \\
10 \text { gram }\end{array}$ & $4.1517 \mathrm{ab}$ & 37.36 \\
$\begin{array}{l}\text { Pupuk NPK } \\
15 \text { gram }\end{array}$ & $2.4550 \mathrm{~b}$ & -18.78 \\
\hline Keterangan: & $\begin{array}{l}\text { Angka yang diikuti oleh huruf yang } \\
\text { sama menunjukkan perlakuan tidak } \\
\text { berbeda nyata pada selang kepercayaan }\end{array}$ \\
& $\begin{array}{l}\text { 95\%. } \\
\end{array}$
\end{tabular}

\section{SIMPULAN}

Pemberian pupuk kompos secara tunggal pada media tailing tidak memberikan pengaruh nyata terhadap parameter tinggi tanaman, diameter, jumlah bintil akar dan nisbah pucuk akar. Namun memberikan pengaruh nyata terhadap berat basah dan berat kering tanaman. Begitu juga dengan pemberian pupuk NPK secara tunggal memberikan pengaruh secara nyata terhadap diameter tanaman, berat basah dan nisbah pucuk akar, namun tidak berpengaruh secara nyata terhadap tinggi tanaman, berat kering dan jumlah bintil akar. Pengaruh interaksi perlakuan pemberian pupuk kompos NPK dengan dosis 5 gram dan kompos 100 gram merupakan komposisi terbaik dari media tanam semai P.falcataria karena dapat meningkatkan pertumbuhan semai P.falcataria khususnya pada pertumbuhan diameter batang. Perlakuan ini memberikan persentase peningkatan terhadap control sebesar $170.37 \%$. sehingga perlakuan pemberian pupuk dengan dosis NPK 5 gram dan kompos 100 gram dapat menjadi rekomendasi untuk kegiatan revegetasi agar tanaman sengon dapat tumbuh dengan optimal. Kadar Ca yang sangat tinggi pada media tanah akan bersifat toksik bagi tanaman sengon.

\section{DAFTAR PUSTAKA}

Adinugraha HA. 2012. Pengaruh cara penyemaia dan pemupukan NPK terhadap pertumbuhan bibit mahoni daun lebar di persemaian. Jurnal Pemuliaan Tanaman Hutan. 6(1):1-10. doi: https://doi.org/10.20886/jpth.20 12.6.1.1-10.

Baskorowati L. 2014. Budidaya Sengon Unggul (Falcataria moluccana) Untuk Pengembangan Hutan Rakyat. Bogor (ID): IPB Press.

Cahyani RW, Hardjana AK. 2017. Perlakuan jenis tanaman dan media tanam pada lahan pasca tambang galian C di KHDTK Labanan, Kabupaten Berau, Kalimantan Timur. Pros Sem Nas Masy Biodiv Indon 3(3):361-367.

El-Aziz NG. 2007. Stimulatory effect of NPK fertilizer and benzyladenine on growth and chemical constituents of Codiaeum variegatum L. plant. American Eurasian J.Agrio \& Environ. Sci. 2(6):711-719

Tabel 7 Hasil analisis tanah pada perlakuan kontrol dan K1N5

\begin{tabular}{cllllll}
\hline No & \multicolumn{1}{c}{ Perlakuan } & \multirow{2}{*}{ Kontrol } & \multicolumn{1}{c}{ Kriteria* } & $\begin{array}{c}\text { NPK dan Kompos } \\
(\text { K1N5) }\end{array}$ & \multicolumn{1}{c}{ Kriteria* } & Perubahan \\
\hline 1 & $\mathrm{pH} \mathrm{H}_{2} \mathrm{O}$ & 7.25 & Netral & 7.34 & Netral & 0.09 \\
2 & C-Organik $(\%)$ & 0.08 & Sangat Rendah & 5.08 & Sangat Tinggi & 5 \\
3 & N-Total $(\%)$ & 0.03 & Sangat Rendah & 0.27 & Sedang & 0.24 \\
4 & P-tersedia $(\mathrm{ppm})$ & 6.07 & Sangat Rendah & 206.21 & Sangat Tinggi & 200.14 \\
5 & $\mathrm{Ca}(\mathrm{me} / 100 \mathrm{~g})$ & 57.68 & Sangat Tinggi & 56.83 & Sangat Tinggi & -0.85 \\
6 & $\mathrm{Mg}(\mathrm{me} / 100 \mathrm{~g})$ & 0.48 & Rendah & 6.98 & Tinggi & 6.5 \\
7 & $\mathrm{~K}(\mathrm{me} / 100 \mathrm{~g})$ & 0.22 & Rendah & 14.93 & Sangat Tinggi & 14.71 \\
8 & $\mathrm{Na}(\mathrm{me} / 100 \mathrm{~g})$ & 0.25 & Rendah & 0.98 & Tinggi & 0.73 \\
9 & $\mathrm{KTK}(\mathrm{me} / 100 \mathrm{~g})$ & 24.22 & Sedang & 32.88 & Tinggi & 8.66 \\
\hline
\end{tabular}

*= Kriteria penilaian sifat kimia tanah (Departemen Pertanian 1983) 
Hardjowigeno S. 2003. Ilmu Tanah Cetakan Kelima. Jakarta (ID): Akademika Pressindo.

Gintinng EV, Sutandi A, Nugroho B, Indriyati LT. 2013. Rasio dan kejenuhan hara $\mathrm{K}, \mathrm{Ca}, \mathrm{Mg}$ di dalam tanah untuk tanaman kelapa sawit (Elaeis guineensi Jacq). J. Tanah Lingk. 15(2):60-65.

Prayudyaningsih R, Sari R. 2016. Aplikasi fungi mikoriza arbuskula (FMA) dan kompos untuk meningkatkan pertumbuhan semai jati (Tectona grandis Linn.f.) pada media tanah bekas tambang kapur. Jurnal Penelitian Kehutanan Wallacea. 5(1):37-46.

Rahmawati V, Sumarsono, Slamet W. 2013. Nisbah daun batang, nisbah tajuk akar dan kadar serat kasar alfalfa (Medicago sativa) pada pemupukan nitrogen dan tinggi defoliasi berbeda. Animal Agriculture Journal. 2(1):1-8.

Stell RGD, Torries JH. 1991. Statistical Principles and Procedures, A Biometric Approach. PT Gramedia Pustaka Utama Jakarta , pp 149-167.

Sastrosupadi A. 2000. Rancangan Percobaan Praktis Bidang Pertanian. Yogyakarta (ID): Kanisius.

Sukendro A, Sugiarto E. 2012. Respon pertumbuhan anakan Shorea leprosula Miq, Shorea

mecistopteryx Ridley, Shorea ovalis (Korth) Blume dan Shoreaselanica (DC) Blume terhadap tingkat intensitas cahaya matahari. Jurnal Silvikultur Tropika. 3(1) :22-27.
Suryantini. 2013. Pembintilan dan penambatan nitrogen pada tanaman kacang tanah. Monograf Balitkabi No 13. 234-250.

Wasis B, Sandrasari A. 2011. Pengaruh pemberian pupuk komps terhadap pertumbuhan semai mahoni (Swietenia macrophylla King.) pada media tanah bekas tambang emas (tailing). Jurnal Silvikultur Tropika. 3(1):109-112.

Wasis B, Fathia N. 2011. Pertumbuhan semai gmelina dengan berbagai dosis pupuk kompos pada media tanah bekas tambang emas. JMHT. 17(1):29-33.

Wasis B, Winata B, Andriani R. 2018. Growth of Agathis dammara (Lamb. Rich.) seedling on gold tailing with addition of coconut shell charcoal and compost. Archives of Agriculture and Environmental Science 3(2): 131-136.

Wulandari AS, Mansur I, Sugiarti H. 2011. Pengaruh pemberian kompos batang pisang terhadap pertumbuhan semai jabon (Anthocephalus cadamba Miq.). Jurnal Silvikultur Tropika. 3(1):78-81.

Zulkifli A. 2013. Pengelolaan Tambang Berkelanjutan. Jakarta (ID): Graha Ilmu. 